\title{
Efficient translation of synthetic and natural mRNAs in an mRNA- dependent cell-free system from the dimorphic fungus Candida albicans
}

\author{
David R. Colthurst, ${ }^{1}$ Peter Chalk, ${ }^{2}$ Mike Hayes ${ }^{2}$ and Michael F. Tuite ${ }^{1 *}$ \\ ${ }^{1}$ Biological Laboratory, The University of Kent, Canterbury, Kent CT2 7NJ, UK \\ ${ }^{2}$ Glaxo Group Research, Greenford Road, Greenford, Middlesex UB6 OHE, UK
}

(Received 24 August 1990; revised 28 November 1990; accepted 6 December 1990)

\begin{abstract}
An mRNA-dependent cell-free translation system has been developed from the human pathogenic fungus Candida albicans using either $\mathrm{S} 30$ or S100 lysates prepared from glass-bead-disrupted whole cells. Translation of the synthetic template poly(U) in this system is highly efficient at temperatures up to $37^{\circ} \mathrm{C}$ and is ATP-dependent. Studies using a range of elongation-specific inhibitors suggest that the mechanism of translational elongation in $C$. albicans is similar to that of another yeast, Saccharomyces cerevisiae. A micrococcal-nuclease-treated $C$. albicans S100 lysate was able to translate exogenously-supplied homologous mRNAs, and a range of heterologous natural mRNAs, using an initiation mechanism that is inhibited by the antibiotic edeine and the $5^{\prime}$ cap analogue 7methylguanosine $5^{\prime}$-monophosphate $\left(\mathrm{m}^{7} \mathrm{GMP}\right)$. As with cell-free lysates prepared from $S$. cerevisiae, the $C$. albicans lysate is unable to initiate translation upon natural mRNAs at temperatures above $20^{\circ} \mathrm{C}$.
\end{abstract}

\section{Introduction}

The pathogenic fungus Candida albicans has been the subject of increasing interest, generated in part by its potential to cause disease in human patients with immune deficiencies (e.g. AIDS), and by its ability to undergo a dimorphic transition from a unicellular yeastlike organism to a multicellular hyphal form (Odds, 1988). Presently little is known about the cellular mechanisms responsible for either pathogenicity or dimorphism, largely because the appropriate genetic and biochemical tools have yet to be developed to an adequate degree to facilitate the necessary detailed studies of gene structure and function. Methods for overcoming the experimental handicap of studying the genetics of an organism with no known sexual cycle $(C$. albicans is a member of the Deuteromycetes or Fungi Imperfecti) are now becoming available (Kurtz et al., 1988; Magee et al., 1988), but little effort has yet gone into providing the necessary in vitro biochemical assays for the key steps in gene expression, namely transcription and translation.

The development of a cell-free translation system that

Abbreviations: BMV, brome mosaic virus; TMV, tobacco mosaic virus; TLCK, tosyl-lysine chloromethyl ketone; TPCK, tosyl-phenylalanine chloromethyl ketone. is capable of translating either exogenously supplied synthetic or natural mRNA templates has led to a detailed understanding of the mechanism and control of translation in eukaryotes, particularly in mammalian cells, although much of the work in this context has been confined to an 'atypical' cell, the rabbit reticulocyte (Clemens, 1985). Such cell-free systems have also been valuable in defining the mode of action of inhibitors and in assessing the coding capabilities of genes isolated by molecular cloning and transcribed in vitro using either the SP6 or T7 RNA polymerases (Little \& Jackson, 1987). To provide the ability to carry out such studies in C. albicans, and to complement the increasingly sophisticated molecular genetic experiments with this fungus, requires the development of such a cell-free system.

To date, mRNA-dependent cell-free systems capable of initiating translation upon exogenously supplied natural mRNAs have only been reported for a limited number of fungi, with the most extensively studied being that derived from the budding yeast Saccharomyces cerevisiae (Tuite \& Plesset, 1986). S. cerevisiae cell-free lysates, produced by disruption of either whole cells (Hofbauer et al., 1982) or spheroplasts (Gasior et al., 1979), are only able to translate exogenous mRNAs at temperatures below $23{ }^{\circ} \mathrm{C}$, a property apparently unique to this organism and initially thought to be due to a temperature-activated nuclease (Herrera et al., 1979). 
Recent evidence has shown, however, that this inhibition of translation at high temperatures is reversible (Mandel \& Trachsel, 1989).

In this paper we report the development of an active cell-free system from $C$. albicans that translates efficiently both the synthetic template polyuridylic acid [poly(U)], and a range of exogenously supplied homologous and heterologous mRNAs. In addition, we demonstrate that the mechanisms of initiation and elongation in C. albicans are very similar to those of $S$. cerevisiae.

\section{Methods}

Strains. Candida albicans strain 2005E (ATCC 10261) was obtained from Glaxo Group Research, Greenford. Saccharomyces cerevisiae strain ABYSI, a protease-deficient strain, was obtained from Dr D. H. Wolf (Freiburg, FRG).

Materials. Biochemicals were obtained from Boehringer Mannheim (BCL), unless otherwise stated. Leupeptin was purchased from the Peptide Institute, Japan. Micrococcal nuclease was obtained from Worthington Biochemicals. Sephadex G-25-150 and $\mathrm{m}^{7}$ GMP were obtained from Sigma. Edeine was a kind gift from Dr B. S. Cox (Oxford, UK) and glass beads ( $0.4 \mathrm{~mm}$ diameter) were obtained from BDH. $\left[{ }^{3} \mathrm{H}\right]$ Phenylalanine $\left(53 \mathrm{Ci} \mathrm{mmol}^{-1} ; 1.96 \mathrm{TBq} \mathrm{mmol}^{-1}\right)$ and $\left[{ }^{35} \mathrm{~S}\right]-$ methionine $\left(1000 \mathrm{Ci} \mathrm{mmol}^{-1} ; 37 \mathrm{TBq} \mathrm{mmol}^{-1}\right)$ were purchased from Amersham, UK.

Preparation of cell-free lysates. C. albicans was grown in YEPD $(1 \%$, $\mathrm{w} / \mathrm{v}$, yeast extract, $1 \%, \mathrm{w} / \mathrm{v}$, bactopeptone, $2 \%, \mathrm{w} / \mathrm{v}$, glucose) at $37^{\circ} \mathrm{C}$ to early exponential phase $\left(1-3 \times 10^{7}\right.$ cells $\left.\mathrm{ml}^{-1}\right)$. Cells were harvested at 2500 r.p.m. for $15 \mathrm{~min}$ at $4{ }^{\circ} \mathrm{C}$, washed with cold sterile water and resuspended in cold lysis buffer A $(20 \mathrm{~mm}-\mathrm{Hepes} / \mathrm{KOH}, \mathrm{pH} 7 \cdot 4$, $100 \mathrm{~mm}$-potassium acetate, $2 \mathrm{mM}$-magnesium acetate, $2 \mathrm{~mm}$-dithiothreitol) at $1 \mathrm{ml}$ per $2 \mathrm{~g}$ wet weight of cells. Buffer A was supplemented with the following protease inhibitors; phenylmethylsulphonyl fluoride (PMSF), $0.5 \mathrm{mM}$; benzamidine. $\mathrm{HCl}, 0.5 \mathrm{mM}$; tosyl-lysine chloromethyl ketone (TLCK), $0.1 \mathrm{mM}$; tosyl-phenylalanine chloromethyl ketone (TPCK), $0.1 \mathrm{~mm}$; and leupeptin, $0.1 \mu \mathrm{g} \mathrm{ml}^{-1}$.

The cell slurry was transferred to a sterile $50 \mathrm{ml}$ Oakridge centrifuge tube and chilled on ice. Acid-washed and baked glass beads were added to just below the meniscus. The tube was tightly capped and shaken vigorously by hand in an 'up-and-down' motion for $30 \mathrm{~s}$, then placed on ice for a further $30 \mathrm{~s}$ (Hussain \& Liebowitz, 1986). This was repeated for eight cycles of shaking and cooling, and the degree of lysis checked microscopically. If necessary, shaking was continued to achieve the desired level (greater than $90 \%$ ) of cell lysis. The glass beads were left to settle out in the tubes held on ice and the supernatant was transferred with a sterile pipette to a sterile baked $30 \mathrm{ml}$ Corex tube. The beads were then washed with a further $1 \mathrm{ml}$ of lysis buffer $\mathrm{A}$ and the supernatants combined.

For the poly(U)-dependent cell-free translation system, the lysate was centrifuged at $30000 \mathrm{~g}$ for $15 \mathrm{~min}$ at $4{ }^{\circ} \mathrm{C}$. For the natural mRNAdependent cell-free translation system, the lysate was initially centrifuged at $13000 \mathrm{~g}$ for $10 \mathrm{~min}$ at $4^{\circ} \mathrm{C}$, and the supernatant from this step centrifuged at $100000 \mathrm{~g}$ for $30 \mathrm{~min}$ at $4{ }^{\circ} \mathrm{C}$ to produce a postpolysomal fraction, as described previously (Tuite \& Plesset, 1986).

The $\mathbf{S} 100$ or $\mathbf{S} 30$ supernatants were applied to a Sephadex G-25-150 column $(1.6 \times 30 \mathrm{~cm})$ equilibrated in buffer B (buffer A plus $20 \%, \mathrm{v} / \mathrm{v}$, glycerol) containing the protease inhibitors detailed above. The column was then eluted with buffer B and $2 \mathrm{ml}$ fractions collected. The $A_{260}$ of the eluting fractions was measured and the fractions with peak absorbances were put individually into sterile microcentrifuge tubes, frozen on dry ice and stored at $-80^{\circ} \mathrm{C}$, where they maintained their protein synthetic activity for several months.

Preparation of $m R N A$ templates. The synthetic template poly $(\mathrm{U})$ was purchased from Boehringer Mannheim. Crude mRNA samples were prepared from $S$. cerevisiae and $C$. albicans essentially as described by Tuite $e t$ al. (1980) using the polysomes pelleted during the preparation of the $\mathrm{S} 100$ post-polysomal lysates (see above). $\mathrm{Poly}\left(\mathrm{A}^{+}\right)$RNA was not prepared because previous studies have demonstrated that such highly purified mRNA samples translate relatively inefficiently in $S$. cerevisiae cell-free lysates (Gasior et al., 1979). TMV RNA was purchased from Amersham. BMV RNA was prepared from purified BMV particles (generously provided by Dr B. S. Cox, University of Oxford) essentially as previously described (Santos et al., 1990).

Cell-free translation assays. Assays $(25 \mu \mathrm{l})$ were performed essentially as described by Tuite \& Plesset (1986) with the following modification: treatment with micrococcal nuclease was performed in the presence of $1 \mathrm{mM}-\mathrm{CaCl}_{2}$ and this incubation was stopped by the addition of $2 \mathrm{~mm}-$ EGTA. The final concentrations in this $25 \mu \mathrm{l}$ assay were as follows unless otherwise stated in the text: $20 \mathrm{~mm}-\mathrm{Hepes} / \mathrm{KOH} \mathrm{pH} \mathrm{7.4,} 2 \mathrm{~mm}$ dithiothreitol, $180 \mathrm{~mm}$-potassium acetate, $1.5 \mathrm{mM}$-magnesium acetate, $430 \mu \mathrm{M}$-ATP, $90 \mu \mathrm{M}$-GTP, $22 \mathrm{~mm}$-creatine phosphate, $70 \mu \mathrm{g}$ creatine phosphokinase $\mathrm{ml}^{-1}, 40 \mathrm{~mm}$ total amino acids, $200 \mu \mathrm{g} \mathrm{mRNA} \mathrm{ml}^{-1}$, $0.5-1.0 \mu \mathrm{Ci}\left[{ }^{3} \mathrm{H}\right]$ phenylalanine or $2-5 \mu \mathrm{Ci}\left[{ }^{35} \mathrm{~S}\right]$ methionine.

The incorporation of radiolabelled amino acids into protein in the cell-free assays was determined by spotting $20 \mu$ l volumes onto a $2.5 \mathrm{~cm}$ Whatman $3 \mathrm{MM}$ filter disc, which was then dropped into ice-cold $5 \%$ $(w / v)$ TCA. After at least $10 \mathrm{~min}$ in TCA, the filters were washed successively with: $200 \mathrm{ml} \mathrm{5 \%} \mathrm{TCA}$ at room temperature; $200 \mathrm{ml}$ boiling $5 \%$ TCA for $5 \mathrm{~min}$, and finally $200 \mathrm{ml} 5 \%$ TCA at room temperature. The filters were then rapidly swirled in $100 \mathrm{ml}$ each of ethanol, ethanol/acetone $(1: 1, \mathrm{v} / \mathrm{v})$ and acetone, after which they were separated and dried at $60^{\circ} \mathrm{C}$ for $30 \mathrm{~min}$. The dried filters were placed in a scintillant (LKB Optiphase $\mathrm{T}$ with $10 \%, \mathrm{v} / \mathrm{v}, \mathrm{H}_{2} \mathrm{O}$ ) and their radioactivity measured in a Beckman LS7800 scintillation counter. All assays were carried out in duplicate and the means calculated.

Analysis of cell-free translation products. Following incubation of the cell-free translation system for $60 \mathrm{~min}$ at $20^{\circ} \mathrm{C}$ with $\left[{ }^{35} \mathrm{~S}\right]$ methionine, a $5 \mu \mathrm{l}$ sample was used to measure radioactivity incorporated into protein. The remainder was treated with ribonuclease $\mathrm{A}\left(100 \mu \mathrm{g} \mathrm{ml}^{-1}\right)$ at $20^{\circ} \mathrm{C}$ for a further $5 \mathrm{~min}$. Subsequent SDS-PAGE analysis and autoradiography were as previously described (Tuite et al., 1980).

Preparation of aminoacylated $\left[{ }^{3} H\right] t R N A^{\text {Phe }}$. C. albicans was grown to a cell density of $1 \times 10^{8}$ cells $\mathrm{ml}^{-1}$, harvested by centrifugation, washed once in cold double-distilled water and frozen at $-70{ }^{\circ} \mathrm{C}$ for $30 \mathrm{~min}$. The cells were then gently thawed and resuspended in $15 \mathrm{ml}$ buffer $\mathrm{J}$ (20 mM-Hepes/KOH pH 7.5, $100 \mathrm{~mm}$-potassium acetate, $5 \mathrm{~mm}$-magnesium acetate, $1 \mathrm{~mm}$-dithiothreitol) and lysed by five passages through a French pressure cell (Amicon). The resulting lysate was centrifuged at $30000 \mathrm{~g}$ for $2 \mathrm{~h}$ at $4{ }^{\circ} \mathrm{C}$ and the supernatant from this was further centrifuged at $100000 \mathrm{~g}$ for $2 \mathrm{~h}$ at $4^{\circ} \mathrm{C}$. The resulting $\$ 100$ supernatant was then dialysed for $16 \mathrm{~h}$ against $2 \times 11$ buffer $\mathrm{K}(50 \mathrm{~mm}-\mathrm{Tris} / \mathrm{HCl}$ $\mathrm{pH} 7.6,10 \mathrm{~mm}$-magnesium chloride, $150 \mathrm{~mm}$-potassium chloride). The dialysed extract was then applied to a DEAE-cellulose column $(3 \times 10 \mathrm{~cm})$ equilibrated with buffer $\mathrm{K}$ and the column washed extensively with this buffer. Fractions containing aminoacyl-tRNA synthetase activity were identified as described below, then pooled and dialysed against buffer $\mathrm{L}$ ( $20 \mathrm{~mm}$-Tris/ $\mathrm{HCl} \mathrm{pH} 7.6,20 \mathrm{~mm}$-potassium chloride, $1 \mathrm{mM}$-dithiothreitol, $2 \mathrm{mM}$-EDTA, $10 \%$, v/v, glycerol) for $2 \mathrm{~h}$ at $4{ }^{\circ} \mathrm{C}$. The dialysed pooled fractions were applied to a phosphocellulose column $(1.5 \times 7 \mathrm{~cm})$ equilibrated with buffer $\mathrm{L}$. The column was eluted with buffer $\mathrm{L}$ containing $100 \mathrm{~mm}$-potassium chloride, then with 
buffer L containing $250 \mathrm{~mm}$-potassium chloride. Aminoacyl-tRNA synthetase activity eluted in the $100 \mathrm{~mm}$-salt wash. The peak fractions were pooled and used as a tRNA-depleted aminoacyl-tRNA synthetase preparation for the aminoacylation of $t \mathrm{RNA}^{\text {Phe }}$.

A $2.5 \mathrm{ml}$ reaction mixture containing $100 \mu \mathrm{Ci}\left[{ }^{3} \mathrm{H}\right]$ phenylalanine, $1 \mathrm{mg}$ E.coli tRNA ${ }^{\text {Phe }}$ (BCL), $4 \mathrm{~mm}$-ATP, 0.1 mM-CTP, $12 \mathrm{~mm}$-magnesium chloride, $20 \mathrm{mM}$-HEPES/KOH pH 7.5, $1 \mathrm{~mm}$-dithiothreitol and $500 \mu \mathrm{l}$ of the crude tRNA-depleted aminoacyl-tRNA synthetase preparation was incubated at $25^{\circ} \mathrm{C}$ for $30 \mathrm{~min}$ then cooled on ice for $10 \mathrm{~min}$. The reaction mixture was then loaded onto a $1 \mathrm{ml}$ DEAEcellulose column and washed extensively with buffer $\mathrm{K}(150 \mathrm{mM}-$ potassium chloride), then the $\left[{ }^{3} \mathrm{H}\right] \mathrm{tRNA} \mathrm{A}^{\text {Phe }}$ was eluted with buffer $\mathrm{K}$ (500 mM-potassium chloride). The peak fractions of charged tR NA ${ }^{\text {Phe }}$ were pooled, precipitated at $-20^{\circ} \mathrm{C}$ for $16 \mathrm{~h}$ with 2.5 vols ethanol $(95 \%, v / v)$ and dried.

\section{Results}

\section{Translation of synthetic templates}

Extensive studies with $S$. cerevisiae cell-free lysates (Sissons, 1978) have shown that to translate the synthetic template poly $(\mathrm{U})$ into poly-phenylalanine only requires a functional elongation system comprising cytoplasmic ribosomes, elongation factors, ATP and GTP, providing the reaction is carried out at very high, non-physiological $\mathrm{Mg}^{2+}$ concentrations to 'force' initiation on the synthetic template. An S30 lysate prepared by glass bead disruption of exponentially growing cells of $C$. albicans (see Methods for details) was found to translate poly(U) with very high efficiency in a template- and $\mathrm{Mg}^{2+}$ dependent manner. Incorporation of $\left[{ }^{3} \mathrm{H}\right]$ phenylalanine was linear for $20 \mathrm{~min}$ at $20^{\circ} \mathrm{C}$, with a complete cessation of protein synthesis by $30 \mathrm{~min}$. Efficient translation of poly $(\mathrm{U})$ only occurred in the $C$. albicans lysate at $\mathrm{Mg}^{2+}$ concentrations between 10 and $25 \mathrm{~mm}$, with the optimum being about $15 \mathrm{~mm}$ (results not shown).

Table 1 summarizes the basic parameters for efficient translation of poly(U) in the C. albicans S30 lysate and shows that they are very similar to those previously obtained for an equivalent $S$. cerevisiae S30 lysate (Tuite \& Plesset, 1986; M. F. Tuite, unpublished data).

\section{Translational elongation mechanism in C. albicans and S. cerevisiae}

A wide range of antibiotics are available that have welldocumented effects on specific steps in the translational elongation cycle of eukaryotes (Vazques \& Jiminez, 1980). Table 2 shows the $I_{50}$ values of a selection of antibiotics in both $C$. albicans and $S$. cerevisiae S30 lysates. These antibiotics affect aminoacyl-tRNA binding to the ribosome, peptide bond formation, or translocation of the ribosome. With the exception of cycloheximide, the inhibitors examined appeared to be
Table 1. Comparison of the optimal parameters for the translation of the synthetic template poly $(U)$ in $C$. albicans and $S$. cerevisiae $S 30$ lysates

\begin{tabular}{lcc}
\hline \hline & \multicolumn{2}{c}{ Optimal conditions } \\
\cline { 2 - 3 } \multicolumn{1}{c}{ Parameter } & $\begin{array}{c}\text { C. albicans } \\
\text { lysate }\end{array}$ & $\begin{array}{c}\text { S. cerevisiae } \\
\text { lysate* }\end{array}$ \\
\hline Time of incubation & $20-30 \mathrm{~min}$ & $20-30 \mathrm{~min}$ \\
Mg $^{2+}$ concn & $15 \mathrm{mM}$ & $12 \mathrm{mM}$ \\
Potassium acetate & $180 \mathrm{~mm}$ & $150 \mathrm{mM}$ \\
concn & $30-37{ }^{\circ} \mathrm{C}$ & $30-37{ }^{\circ} \mathrm{C}$ \\
Temperature & $1 \cdot 2-1.6 \mathrm{mg} \mathrm{ml}^{-1}$ & $\mathrm{ND}$ \\
Protein concn & $500 \mu \mathrm{g} \mathrm{ml}^{-1}$ & $400 \mu \mathrm{g} \mathrm{ml}$ \\
Poly(U) concn & & \\
\hline \hline
\end{tabular}

ND, not determined.

* Data from Tuite \& Plesset (1986) and M. F. Tuite (unpublished).

Table 2. Inhibition of translational elongation in cell-free systems from $S$. cerevisiae and $C$. albicans by antibiotics

For each antibiotic seven different concentrations were used to determine the $I_{50}$ value, i.e. the concentration, in $\mu \mathrm{g} \mathrm{ml}^{-1}$, required to give $50 \%$ inhibition of $\left[{ }^{3} \mathrm{H}\right]$ phenylalanine incorporation in a poly(U)-programmed cell-free system.

\begin{tabular}{clcc}
\hline \hline & & \multicolumn{2}{c}{$\mathrm{I}_{50}\left(\mu \mathrm{g} \mathrm{ml}^{-1}\right)$} \\
\cline { 3 - 4 } $\begin{array}{c}\text { Site of } \\
\text { action* }\end{array}$ & \multicolumn{1}{c}{ Antibiotic } & $\begin{array}{c}\text { S. cerevisiae } \\
\text { lysate }\end{array}$ & $\begin{array}{c}\text { C. albicans } \\
\text { lysate }\end{array}$ \\
\hline 1 & Tetracycline & 110 & 75 \\
2 & Fusidic acid & 85 & 200 \\
3 & Puromycin & 19 & $4 \cdot 5$ \\
& Cycloheximide & $0 \cdot 2$ & 200 \\
& Emetine & 65 & 65 \\
\hline \hline
\end{tabular}

* 1, Aminoacyl-tRNA binding to the ribosome; 2, peptide bond formation; 3 , ribosomal translocation.

equally effective against both the $C$. albicans and $S$. cerevisiae translational elongation systems, suggesting that the partial elongation steps are very similar in the two fungi. The resistance to cycloheximide observed in the $C$. albicans lysate strongly suggests that $C$. albicans shows natural resistance to cycloheximide, a not uncommon property of many species of fungi including some strains of $S$. cerevisiae (Rao \& Grollman, 1967). Such resistance is probably due to a natural variation in the structure of a ribosomal protein of the 60S subunit (Fried \& Warner, 1982).

The poly(U)-dependent cell-free system of $S$. cerevisiae has also been shown to exhibit a very specific requirement for ATP to allow the functioning of translation elongation factors independent of aminoacylation 


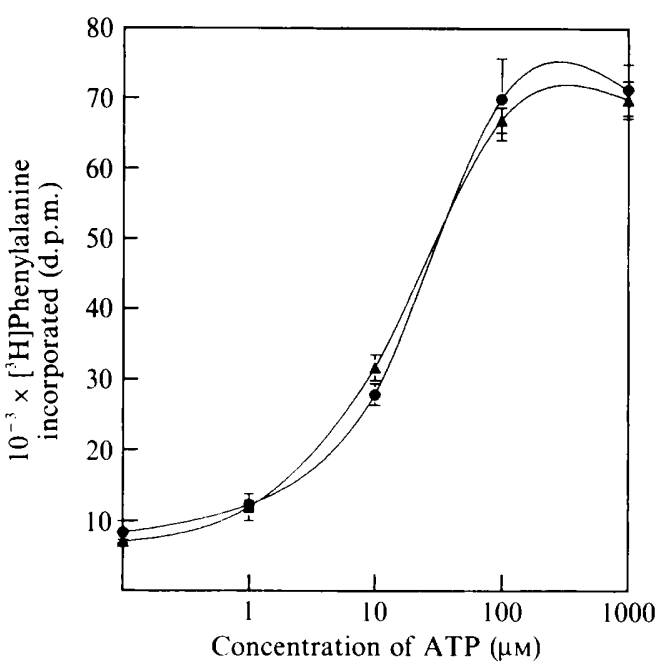

Fig. 1. Effect of increasing ATP concentrations on the translation of the synthetic template poly( $(\mathrm{U})$, in an $\mathrm{S} 30$ cell-free lysate of $C$. albicans, in the absence ( $)$ or presence ( $\Delta$ ) of $0.3 \mathrm{~mm}$-GTP added exogenously.

(Skogerson, 1979; Uritani \& Miyazaki, 1988). Fig. 1 shows that the $C$. albicans poly(U)-dependent system also has a strict requirement for ATP. To demonstrate this, the $C$. albicans cell-free system was supplemented with purified tRNA ${ }^{\text {Phe }}$ aminoacylated in vitro with $\left[{ }^{3} \mathrm{H}\right]$ phenylalanine, in place of $\left[{ }^{3} \mathrm{H}\right]$ phenylalanine alone, to make the system independent of the ATP requirement for aminoacylation. The ATP requirement for elongation was saturated at $100 \mu \mathrm{M}$ and could not be substituted for by increased concentrations of GTP (data not shown). In contrast, the requirement for GTP was less strict and significant levels of translation could be obtained in the absence of exogenously supplied GTP, providing ATP was present in concentrations $\geqslant 10^{-5} \mathrm{M}$. These results suggests that, like $S$. cerevisiae, $C$. albicans has an ATPdependent translation elongation factor (or factors) absolutely required for poly $(\mathrm{U})$ translation in vitro.

\section{Translation of exogenous natural $m R N A s$}

For a cell-free translation system to be of wide use it must be able to translate a wide range of natural mRNAs both efficiently and authentically in a concentration-dependent manner. This requires, in turn, that the cell-free system can be made free of endogenous mRNAs by treating the cell-free lysate with micrococcal nuclease (Pelham \& Jackson, 1976). Preliminary experiments with an S100 lysate of C. albicans (see Methods) indicated that endogenous mRNAs could be effectively removed by treating the lysates with $25 \mu \mathrm{g}$ micrococcal nuclease $\mathrm{ml}^{-1}$ for $15 \mathrm{~min}$. To establish whether such an mRNAdepleted system could now translate exogenously sup- plied natural mRNA, total RNA prepared from $C$. albicans polysomes was used to programme the system at $20^{\circ} \mathrm{C}$. Over a range of $\mathrm{Mg}^{2+}$ concentrations the addition of the C. albicans polysomal RNA stimulated incorporation of $\left[{ }^{3} \mathrm{H}\right]$ phenylalanine into protein by between 10 and 15 -fold, with the maximal efficiency being observed at $1.5 \mathrm{~mm}-\mathrm{Mg}^{2+}$ (data not shown). This value is in good agreement with the $\mathrm{Mg}^{2+}$ optimum observed with the $S$. cerevisiae mRNA-dependent cell-free system (Tuite et al., 1980). The optimal potassium acetate concentration for translation of the C. albicans polysomal RNA was found to be $160 \mathrm{~mm}$ (data not shown), again in good agreement with the $\mathrm{K}^{+}$optimum of the $S$. cerevisiae cellfree system (Tuite et al., 1980).

To examine the nature of the translation products being synthesized in the $C$. albicans lysate, proteins were labelled with $\left[{ }^{35}\right.$ S $]$ methionine in vitro and analysed by one-dimensional SDS-PAGE. As shown in Fig. 2, there was a high level of endogenous protein synthesis in the $C$. albicans lysate which could be entirely eliminated by treating the lysate with micrococcal nuclease (compare lanes 1 and 2). Furthermore this micrococcal-nucleasetreated lysate was able to translate exogenously supplied complex mixtures of both heterologous (Fig. 2, lane 3) and homologous (Fig. 2, lane 6) mRNAs. That this translation was being mediated by natural initiation mechanisms was indicated by the strong inhibition of translation of exogenously supplied homologous and heterologous mRNAs by two initiation-specific inhibitors, edeine and the $5^{\prime}$ mRNA cap analogue $\mathrm{m}^{7} \mathrm{GMP}$ (Fig. 2, lanes 4, 5 and 7, 8), as found previously for the analogous $S$. cerevisiae cell-free system (Tuite et al., 1980; Tuite and Plesset, 1986).

In an attempt to improve the in vitro synthesis of highmolecular-mass proteins we supplemented the $C$. albicans cell-free lysate with either a cocktail of protease inhibitors (see Methods) or human placental ribonuclease inhibitor or a combination of both. As shown in Fig. 3, only the combination of protease and ribonuclease inhibitors significantly improved the level of incorporation and synthesis of high-molecular-mass proteins programmed by exogenously supplied $C$. albicans mRNA, with proteins in excess of $100 \mathrm{kDa}$ being detected. The addition of total tRNA from either $C$. albicans or rat liver had no further stimulatory effect (data not shown).

The results presented in Fig. 4 confirm the potential of the system to synthesize polypeptides with molecular masses in excess of $100 \mathrm{kDa}$. In this case the system was programmed with TMV RNA (Fig. 4, lane 3). The ability of the $C$. albicans lysate to translate a second plant viral RNA genome is shown in Fig. 4, lane 2; unfractionated BMV RNA directed the synthesis of a single major polypeptide, the $19 \mathrm{kDa}$ coat protein, 


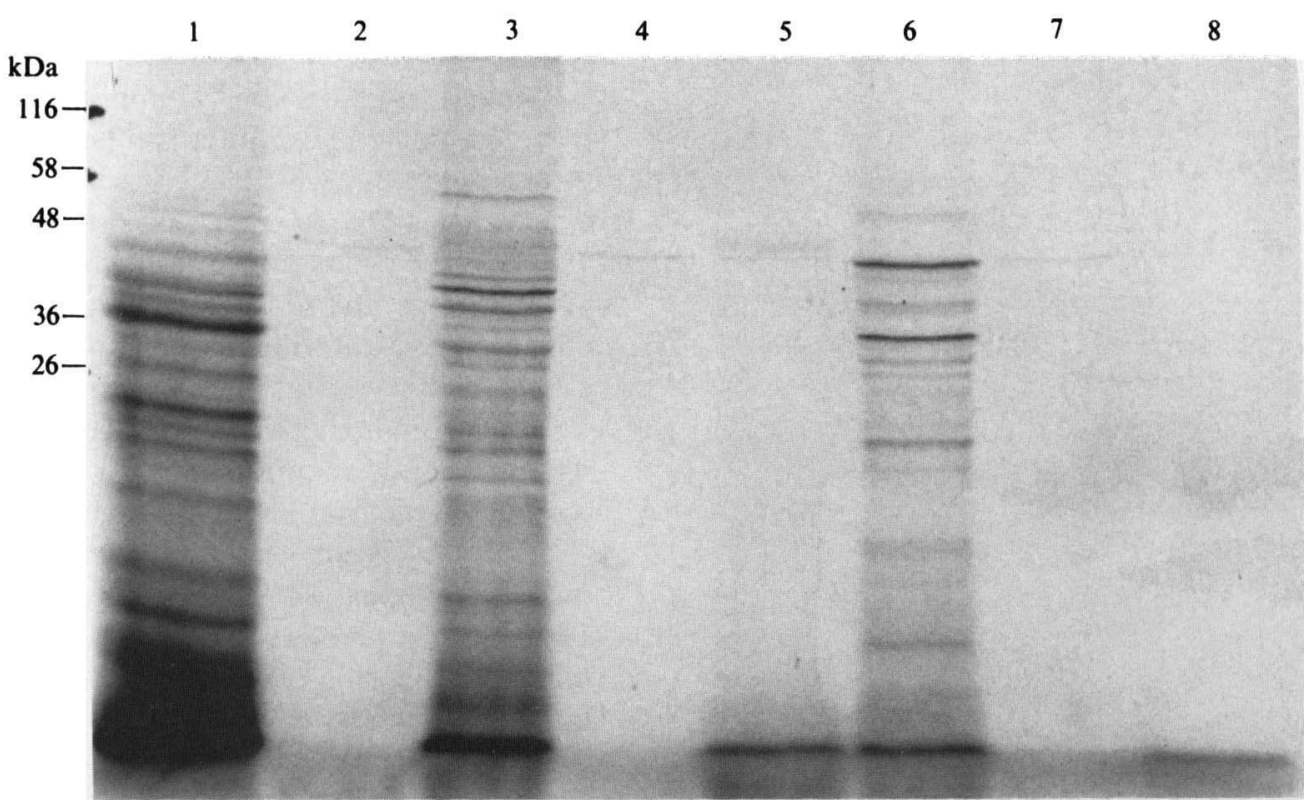

Fig. 2. The products of translation of homologous (C. albicans) and heterologous (S. cerevisiae) mRNAs in a C. albicans $\mathrm{S} 100$ lysate. Lane 1 , endogenous protein synthesis prior to treatment with micrococcal nuclease; lane 2, endogenous protein synthesis after treatment with micrococcal nuclease $\left(25 \mu \mathrm{g} \mathrm{ml}^{-1}\right)$; lane 3, as for lane 2 except programmed with polysomal RNA from $S$. cerevisiae

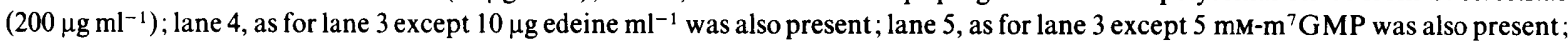
lane 6, as for lane 2 except programmed with polysomal RNA from C. albicans $\left(200 \mu \mathrm{g} \mathrm{ml}^{-1}\right)$; lane 7 , as for lane 6 except $10 \mu \mathrm{g}$ edeine $\mathrm{ml}^{-1}$ was also present; lane 8 , as for lane 6 except $5 \mathrm{mM}-\mathrm{m}^{7} \mathrm{GMP}$ was also present. In vitro translation products were labelled with $\left.{ }^{[35} \mathrm{S}\right]$ methionine and analysed as described in Methods. The positions of molecular mass standards are indicated. NB: The band of 47 $\mathrm{kDa}$ observed in all lanes is an artefact arising from the use of methionine as the label.

although the in vitro-synthesized product migrated slightly more slowly in the gel than authentic BMV coat protein co-electrophoresed on the same gel. We have recently shown that this aberrant migration is due to efficient 'read-through' of the BMV coat protein cistron UAG termination codon by an endogenous tRNA (Santos et al., 1990). We have not, however, observed significant read-through of translational terminators in C. albicans or other natural mRNAs, suggesting that the BMV RNA4 UAG terminator may be leaky with respect to termination (Skuzeski et al., 1990).

One of the unusual characteristics of the $S$. cerevisiae mRNA-dependent cell-free lysate is its sensitivity to temperature, with little or no translation of natural mRNAs being detectable above $20^{\circ} \mathrm{C}$ (Gasior et al., 1979). In a similar way, translation was not detectable in C. albicans cell-free lysates incubated at either $30^{\circ} \mathrm{C}$ or $37^{\circ} \mathrm{C}$ (results not shown), temperatures at which the majority of eukaryotic cell-free translation systems efficiently translate exogenous mRNAs (Clemens, 1985). Failure to translate at temperatures above $25^{\circ} \mathrm{C}$ was observed with exogenously supplied natural mRNAs, and with endogenous-RNA-directed protein synthesis (data not shown). That this temperature sensitivity was not due to a block in translation elongation was confirmed by using the synthetic template poly(U) (Table 3); the elongation efficiency of both the $C$.
Table 3. Translation elongation is not temperature-sensitive in either the $C$. albicans or $S$. cerevisiae cell-free systems, programmed with the synthetic template poly $(U)$

Incorporation of $\left[{ }^{3} \mathbf{H}\right]$ phenylalanine was measured in a $20 \mathrm{~min}$ assay in the absence or presence of poly(U). The data represent means of two independent assays run in parallel.

\begin{tabular}{|c|c|c|c|c|}
\hline \multirow{3}{*}{$\begin{array}{l}\text { Temp. of } \\
\text { incubation } \\
\left({ }^{\circ} \mathrm{C}\right)\end{array}$} & \multicolumn{4}{|c|}{$10^{-3} \times$ Incorporation of $\left[{ }^{3} \mathrm{H}\right]$ phenylalanine (d.p.m.) } \\
\hline & \multicolumn{2}{|c|}{ C. albicans lysate } & \multicolumn{2}{|c|}{ S. cerevisiae lysate } \\
\hline & $\begin{array}{c}\text { Minus } \\
\operatorname{poly}(\mathbf{U})\end{array}$ & $\begin{array}{c}\text { Plus } \\
\text { poly(U) }\end{array}$ & $\begin{array}{c}\text { Minus } \\
\text { poly(U) }\end{array}$ & $\begin{array}{c}\text { Plus } \\
\text { poly(U) }\end{array}$ \\
\hline 20 & $6 \cdot 2$ & $224 \cdot 8$ & 8.7 & 413.9 \\
\hline 30 & $5 \cdot 2$ & $356 \cdot 5$ & $7 \cdot 8$ & $431 \cdot 0$ \\
\hline 37 & $5 \cdot 6$ & $342 \cdot 9$ & $9 \cdot 5$ & $436 \cdot 5$ \\
\hline
\end{tabular}

albicans and $S$. cerevisiae $\mathrm{S} 100$ s was not impaired at either $30^{\circ} \mathrm{C}$ or $37^{\circ} \mathrm{C}$, and the $C$. albicans lysate translated poly(U) optimally at $30^{\circ} \mathrm{C}$.

\section{Discussion}

In many ways the characteristics we describe for the $C$. albicans system are similar to those previously described for an analogous system developed for the budding yeast S. cerevisiae (Gasior et al., 1979; Herrera et al., 1979; 


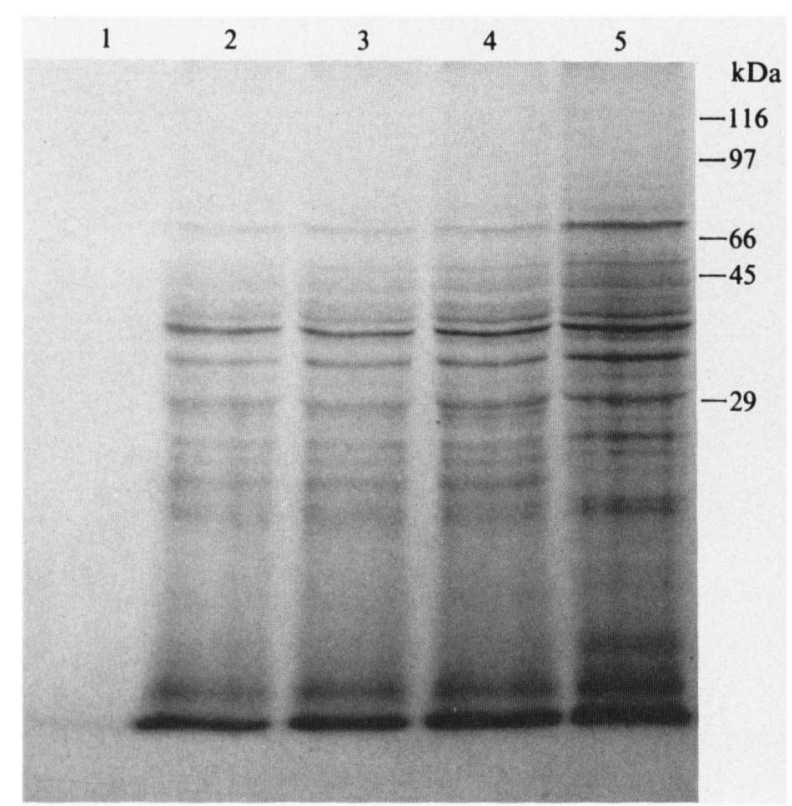

Fig. 3. Effect of addition of protease and ribonuclease inhibitors on the synthesis of translation products programmed by C. albicans mRNA in a micrococcal-nuclease-treated cell-free lysate. Lane 1, no mRNA; Lanes 2-5, as for lane 1 except programmed with polysomal RNA from C. albicans $\left(200 \mu \mathrm{g} \mathrm{ml}^{-1}\right)$. The following additions were made: lane 3 , $0.5 \mathrm{mM}$-PMSF, $0.5 \mathrm{mM}$-benzamidine. $\mathrm{HCl}, 0.1 \mathrm{mM}$-TLCK, $0.1 \mathrm{mM}$ TPCK, $0.1 \mu \mathrm{g}$ leupeptin $\mathrm{ml}^{-1}$ (protease inhibitors); lane 4,1 unit human placental ribonuclease inhibitor; lane 5 , a combination of the components added to lanes 3 and 4 . In vitro translation products were labelled with $\left[{ }^{35}\right.$ S $]$ methionine and analysed as described in Methods. The positions of molecular mass standards are indicated.

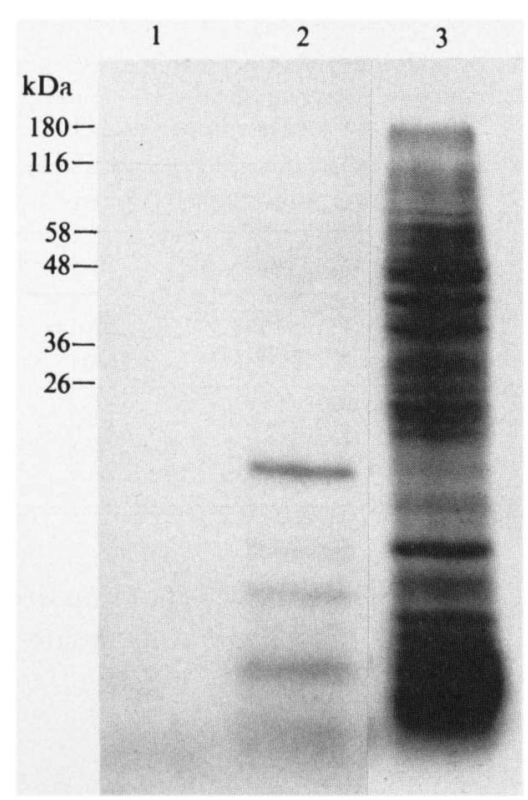

Fig. 4. Translation of plant viral RNAs in a C. albicans $\mathrm{S} 100$ cell-free lysate treated with micrococcal nuclease. Lane 1, no RNA added; lane

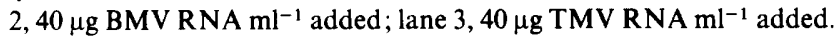
In vitro translation products were labelled with $\left[{ }^{35} \mathrm{~S}\right]$ methionine and analysed as described in Methods. The positions of molecular mass standards are indicated.
Tuite \& Plesset, 1986). In particular, the absolute requirement for exogenously supplied ATP for translation elongation, and the failure of the system to initiate in vitro at temperatures much above $20^{\circ} \mathrm{C}$, appear to be two characteristics unique to yeast cell-free systems (Gasior et al., 1979; Skogerson, 1979). In most other respects ionic requirements, sensitivity to antibiotic inhibitors, ability to translate a wide range of natural mRNAs, etc. the two fungal systems behave very similarly to those developed from higher eukaryotic cells (Clemens, 1985).

The nucleotide requirements (i.e. ATP and GTP) of the crude $C$. albicans elongation system are intriguing. All eukaryotic cells examined to date require two translation elongation factors, each with associated GTPase activities - EF- $1 \alpha$, which mediates tRNA binding to the ribosome, and EF-2, which mediates translocation (reviewed by Moldave, 1985); the yeast $S$. cerevisiae is no exception to this (Skogerson, 1979). However, $S$. cerevisiae has an absolute requirement for a third soluble elongation factor, EF-3 (Skogerson \& Wakatama, 1976). EF-3 is required for the translation of both synthetic and natural mRNAs in vitro (Hutchinson et al., 1984; Herrera et al., 1984) and has an 80Sribosome-dependent GTPase and ATPase activity displayed by the same active site (Uritani \& Miyazaki, 1988). The dramatic stimulation of polyphenylalanine synthesis on yeast ribosomes by ATP, initially described by Skogerson (1979), has now been ascribed to the essential requirement for the ATPase activity of EF-3 during the elongation cycle (Uritani \& Miyazaki, 1988). Our results (Fig. 1) strongly suggest that $C$. albicans may also possess an ATP-dependent elongation factor analogous to the $S$. cerevisiae EF-3. We have shown that $C$. albicans does indeed have a protein of approximate molecular mass $130 \mathrm{kDa}$, that strongly cross-reacts with a polyclonal antibody raised against the $S$. cerevisiae EF-3 translation factor, which has a molecular mass of $125 \mathrm{kDa}$ (D. Colthurst and others, unpublished). The apparent non-requirement for exogenous GTP at high ATP concentrations in the crude $C$. albicans lysate indicates either a high endogenous level of GTP in the S30 lysate or that excess ATP can be used to generate GTP from endogenous GDP.

One unusual aspect of translation in $C$. albicans uncovered by our in vitro translation studies is the failure to recognize the termination codon UAG as such, but rather as a sense codon (Santos et al., 1990).

Our studies with an in vitro translation system developed from $C$. albicans have therefore already provided evidence for there being a number of aspects of the translational machinery of this human pathogen which differ from those of higher eukaryotes and may thus represent potential targets for chemotherapeutic agents. 
We gratefully acknowledge the financial support of Glaxo Group Research and the Nuffield Foundation for this work.

\section{References}

Clemens, M. J. (1985). Translation of eukaryotic messenger RNA in cell-free extracts. In Transcription and Translation: a Practical Approach, pp. 231-270. Edited by B. D. Hames \& S. J. Higgins. Oxford: IRL Press.

Fried, H. M. \& W ARner, J. R. (1982). Molecular cloning and analysis of the yeast gene for cycloheximide resistance and ribosomal protein L29. Nucleic Acids Research 10, 3133-3148.

Gasior, E., Herrera, F., Sadnik, I., MClaughlin, C. S. \& Moldave, K. (1979). The preparation and characterization of a cell-free system from Saccharomyces cerevisiae that translates natural messenger ribonucleic acid. Journal of Biological Chemistry 254, 2965-2969.

Herrera, F., Gasior, E., Mclaughlin, C. S. \& Moldave, K. (1979). Evidence for a nuclease in Saccharomyces cerevisiae that effects the cell-free translation of natural messenger RNA. Biochemical and Biophysical Research Communications 88, 1263-1270.

Herrera, F., Martinez, J. A., Moreno, N., Sadnik, I., MclaughLiN, C. S., Feinberg, B. \& Moldave, K. (1984). Identification of an altered elongation factor in temperature sensitive mutant ts $7^{\prime}-14$ of Saccharomyces cerevisiae. Journal of Biological Chemistry 259, 1434714349.

Hofbauer, R., Fessl, F., Hamilton, B. \& Ruis, H. (1982). Preparation of a mRNA-dependent cell-free translation system from whole cells of Saccharomyces cerevisiae. European Journal of Biochemistry 122, 199-203.

Hussain, I. \& Leibowitz, M. J. (1986). Translation of homologous and heterologous messenger RNAs in a yeast cell-free system. Gene 45, 13-23.

Hutchinson, J. S., Feinberg, B., Rothwell, T. C. \& Moldave, K. (1984). Monoclonal antibody specific for yeast elongation factor 3. Biochemistry 23, 3055-3063.

Kurtz, M. B., Kirsch, D. R. \& Kelly, R. (1988). The molecular genetics of Candida albicans. Microbiological Sciences 5, 58-63.

LiTtle, P. F. R. \& JACKson, I. J. (1987). Application of plasmids containing promoters specific for phage-encoded RNA polymerases. In DNA Cloning: A Practical Approach, vol. 3, pp. 1-18. Edited by D. M. Glover. Oxford: IRL Press.
Magee, P. T., Rikkerink, E. H. A. \& Magee, B. B. (1988). Methods for the genetics and molecular biology of Candida albicans. Analytical Biochemistry 175, 361-372.

Mandel, T. \& Trachsel, H. (1989). Yeast, Saccharomyces cerevisiae, cell-free translation: the inhibition of high temperature is reversible. Biochimica et Biophysica Acta 1007, 80-83.

Moldave, K. (1985). Eukaryotic protein synthesis. Annual Review of Biochemistry 54, 1109-1149.

ODDs, F. C. (1988). Candida and Candidosis, 2nd edn. London : Baillière Tindall.

Pelham, H. R. B. \& Jackson, R. J. (1976). An efficient mRNAdependent translation system from reticulocyte lysates. European Journal of Biochemistry 67, 247-256.

RaO, S. S. \& Grollman, A. P. (1967). Cycloheximide resistance in yeast: a property of the $60 \mathrm{~S}$ ribosomal subunit. Biochemical and Biophysical Research Communications 29, 696-704.

Santos, M., Colthurst, D. R., Wills, N., Mclaughlin, C. S. \& TuITE, M. F. (1990). Efficient translation of the UAG termination codon in Candida species. Current Genetics 17, 487-491.

Sissons, C. H. (1978). Method for yeast protein synthesis in a cell-free system. Methods in Cell Biology 20, 83-99.

SKOGERSON, L. (1979). Separation and characterization of yeast elongation factors. Methods in Enzymology 60, 676-685.

Skogerson, L. \& Wakatama, E. (1976). A ribosome-dependent GTPase from yeast distinct from elongation factor 2. Proceedings of the National Academy of Sciences of the United States of America 73, 73-76.

Skuzeski, J. M., Nichols, L. M. \& Gesteland, R. F. (1990). Analysis of leaky viral translation termination codons in vivo by transient expression of improved $\beta$-glucuronidase vectors. Plant Molecular Biology 15, 65-79.

Tuite, M. F. \& Plesset, J. (1986). mRNA-dependent yeast cell-free translation systems: theory and practice. Yeast 2, 35-52.

Tuite, M. F., Plesset, J., Moldave, K. \& Mclaughlin, C. S. (1980). Faithful and efficient translation of homologous and heterologous mRNAs in an mRNA-dependent cell-free system from Saccharomyces cerevisiae. Journal of Biological Chemistry 255, 8761-8766.

URITANI, M. \& MiYAZAKI, M. (1988). Characterization of the ATPase and GTPase activities of elongation factor 3 (EF-3). purified from yeasts. Journal of Biochemistry 103, 522-530.

VAZQUeS, D. \& Jiminez, A. (1980). In Ribosomes: Structure, Function and Genetics, pp. 847-869. Edited by G. Chambliss, G. R. Graven, J. E. Davies, K. Davis, L. Kahan, \& M. Nomura. Baltimore: University Park Press. 